821.163.41.09-32 Јакшић М. https://doi.org/10.18485/kij.2019.66.2.3

ЈАСМИНА С. ЈОКИТ ${ }^{*}$ ЗОРИЦА П. ХАШИТ

Филозофски факултет у Новом Саду

Одсек за српску књижевност
Оригинални научни рад

Примљен: 13. 11. 2019.

Прихваћен: 02. 12. 2019.

\title{
ФОЛКЛОРНИ ЕЛЕМЕНТИ У ПРИПОВЕДАЧКОМ ОПУСУ МИЛЕТЕ ЈАКШИЋА**
}

\begin{abstract}
У раду се тумаче фолклорни елементи у приповеткама Милете Јакшића. Пишчево интересовање за фолклорне мотиве и фолклорну фантастику било је континуирано, а датира од његових књижевних почетака. Подстицај за обраду фолклорних елемената може се пронаћи у утицају руске књижевности (Гогољ), али још више у Јакшићевој склоности да сакупља и бележи етнографске податке. У фокусу истраживања су приповетке „Стадо”, „Даћа”, „Литија”, „Нечиста кућа”, и „Мистерије”, у којима се препознају примери обредно-обичајне праксе и народних веровања и предања (погребни обичаји, веровања о ђаволу, демонским бићима, злим силама, вилама, вештицама, Тодорским коњима, чудесним исцељењима...) Уочено је да је Милета Јакшић вешто у своју прозу уткао фолклорне елементе и успешно их литерарно обрадио.
\end{abstract}

Кључне речи: Милета Јакшић, приповетке, фолклорни мотиви, фолклорна фантастика, митска/демонска бића, веровања, демонолошка предања.

Књижевни опус Милете Јакшића разнородан је и богат - писао је песме, прозу, драме, радио на књижевности за децу, преводио... ${ }^{1}$ Објавио је две збирке песама истог наслова - Песме - 1899. и 1922. године и три збирке приповедака:

${ }^{*}$ jasmina.jokic@ff.uns.ac.rs zorica_hadzic@ff.uns.ac.rs

*** Рад је настао у оквиру пројекта Аспекти идентитета и юихово обликовање у српској књижевности (178005) који се реализује на Одсеку за српску књижевност Филозофског факултета у Новом Саду.

${ }^{1}$ Милета Јакшић (Српска Црња, 1869 - Београд, 1935), школовао се у родном месту, гимназију похађао у Новом Саду, а матурирао у Осеку. Завршио је Православно богословско училиште у Сремским Карловцима. Започео је, у два наврата, да студира филозофију у Бечу, али му лоше материјално стање није дозвољавало да се на студијама дуже задржи. Радио је као наставник српског језика, историје и омилитике у Монашкој школи при манастиру Хопово. Једно време живео је у Темишвару где је био привремени бележник Епархије темишварске (1901-1903). Вратио се у Црњу и ступио у свештеничку службу. Због љубави према младој учитељици, Зорки Андрејевић, одлучно скида мантију, напушта Црњу и одлази у Нови Сад, где је 1920. добио место библотекара у Матици српској. Наредне године прелази у Београд где ради као секретар Министарства социјалне политике. Умро је 
Приче (1900), Црно маче (1921) и Мирна времена (1935). Опробао се и у дужим прозним формама, остављајући иза себе недовршен роман (Роман усамљена човека), чији су сачувани фрагменти, као и драма Урок, штампани тек у наше време. Један део књижевног опуса Јакшић је посветио деци, објавио је књиге: Сунчаница (1929), Дечја збирка песама и прозе (1929) и Легенде и приче за деиу и одрасле (1931) и приредио два избора песама за децу из дела Јована Јовановића Змаја односно Војислава Илића.

Ушао је у књижевност рано, као ђак новосадске гимназије, носећи терет великог имена - био је синовац Ђуре Јакшића. Иако једнако окренут и поезији и прози, у историји српске књижевности остао је првенствено упамћен као песник - „весник и жртва” модерне српске поезије. Афирмација Милете Јакшића као неправедно скрајнутог приповедача уследила је тек постхумно. Иванка Јовановић, ауторка прве монографије о његовом књижевном делу, на једном месту изнела је неутемељену и неприхватљиву тврдњу да „(...) pripovetke Milete Jakšića znače samo beznačajnu, epizodnu pojavu u razvitku srpske književnosti, nevezanu jače za njen tok" (Jovanović 1959: 330). У даљим, штурим освртима на Јакшићеву приповедну прозу прихватило се мишљење да су његове приповетке анахроне, разрађене скице или анегдоте прожете аутобиографијом. Тек у новије време Милета Јакшић је откривен као приповедач вредан пажње, а у одређеним случајевима и антиципатор модерне српске прозе. ${ }^{2}$ Оцена да је Јакшић прозаиста слабији од Јакшића песника - време је показало - била је пребрзо донета.

Истини за вољу, прве две његове приповедачке збирке биле су, изгледом и опремом, готово неугледне и неприметне. Прва, штампана у Мостару 1900. године, садржала је свега три приповетке („Црквењаково прасе”, „Шта је видео Пера Детлић” и „Црно маче”), од којих су две биле претходно објављене у периодици. ${ }^{3}$ Већ у овој збирци могле су се наслутити различите тематске оријентације и приповедне технике. Иако збирка није имала значајну рецепцију, у малобројним освртима указано је на постојање хуморних елемената, утицај Гогољевих сатирично-алегоријских прича, као и утицај Мамина Сибирјакова (Аноним [Скерлић?] 1901: 490). Истицана је пишчева склоност ка фантастичном, необичном. Поред руских узора, критика је запазила сличности са прозом Е. Т. Хофмана и Е. А. Поа. Друга збирка Црно маче, објављена у Панчеву 1921. године, садржала је осам приповедака: „Црно маче”, „Литија”, „Ђаво”, „Даћа”, „Остављена”, „Новинарска белешка”, „Честитка” и „Ах, Матилда!”. У њој је још више дошла до

\footnotetext{
у Београду и сахрањен је у гробници стрица, Ђуре Јакшића.Радом обележавамо сто педесет година од рођења Милете Јакшића.

${ }^{2}$ Ново читање његових приповедака започело је захваљујући избору из његове прозе Нечиста кућа Светлане Велмар-Јанковић и њеним текстовима.

${ }^{3}$ До појаве прве збирке приповедака, Јакшић је своју објављивао у Отацбини, Српском великокикиндском календару и Стражилову. Приповетка „Црно маче” штампана је у Отаибини 1892. До сада је било непознато да се приповетка „Шта је видео Пера Детлић” први пут појавила у новосадском Бранику 1894. под насловом „Шта је видео господин Детлић”. У наредној збирци Јакшић јој је променио наслов у „Ђаво” да би јој у последњој збирци приповедака вратио првобитни наслов - „Шта је видео Пера Детлић”.
} 
изражаја Јакшићева тематска разноврсност, интересовање за снове, фолклорне мотиве, слике из манастирског живота... Ипак, критика готово да је није приметила. Трећа збирка приповедака објављена је непосредно пред пишчеву смрт у издању Српске књижевне задруге. Обимнија од претходних, била је састављена од петнаест приповедака: „Црно маче”, „Литија”, „Даћа”, „Ах, Матилда!”, „Светац који не помаже”, „Мистерије”, „Rosa, rosae”, „Страх”, „Демон”, „Пророштво”, „Нечиста кућа”, „Други тенор”, „Дубок је корен”, „Новац душогубац” и „Мали брат”. Један број приповедака Милете Јакшића остао је у периодици. Писац их, из ко зна којих разлога, није преносио у збирке.

Радован Вучковић је сачинио једну од могућних подела приповедака Милете Јакшића групишући их у четири типа, према њиховим жанровским и стилским карактеристикама: нерваловско-мопасановски тип, симболички у стилу Тургењевљевих поетизација стварности, фолклорно-фантастични тип у духу Гогоља и, најзад, толстојевско библијско-митолошке фантастике чудесног (Vučković 1990: 131). ${ }^{4}$ Уочљиво је у овој подели инсистирање на утицају руске литературе, што свакако има оправдање и у пишчевој лектири. Уосталом, овакво трагање за могућним пишчевим узорима датира још од критичких приказа његове прве збирке приповедака. Непобитно је да је Јакшић био окренут руској литератури и да је са руског највише и преводио. Његово интересовање за руску књижевност уочено је још у новосадској гимназији - књижевник Јован Протић забележио је да је Гогољ и њега и Јакшића „у школској скамији тако силно заносио" (Протић 1901: 314). Нема сумње да је Јакшић добро познавао дело писца Мртвих душа и врло је могућно да у оном делу своје прозе богате фолклорним мотивима, Јакшић макар и нехотице претрпео Гогољев утицај. Интересовање Милете Јакшића за руску књижевност није никада престајало, а свакако су га у томе подстицали и његови блиски пријатељи Ника Николајевић и Јован Максимовић, обојица врсни преводиоци са руског језика. Њихова преписка открива да су често размењивали књиге руских писаца, консултовали се и саветовали у вези са преводима које су радили, указивали на интересантне књиге руских писаца. Међутим, Јакшић је као прозни писац најпре био аутентичан и свој, а не само пуки епигон руских и француских класика (Хаџић 2012: 244). Још је Светлана Велмар-Јанковић посматрала и Јакшића и Диса као писце који утицаје примају површно и да их „препознају, можда, једино као светлосне путоказе на своме тамном путу" (Велмар-Јанковић 1985: 283).

Уосталом, да је Јакшић добро познавао руске, немачке и француске приповедаче, потврђују и његове бележнице. У њима је водио дневничке белешке, записивао скице за приповетке, стихове, концепте за роман, размишљања и импресије из свакодневног живота. Често се на њиховим страницама могу пронаћи исписи и преписи из књига које је читао (Шилер, Шекспир, Гете, Русо...). Сачуване су и бележнице које су му служиле за вежбање у руском и француском, као

\footnotetext{
${ }^{4}$ Читаоце упућујемо и на поделу Јакшићеве прозе у књизи Милице Томовић Приповедни свет Милете Јакиића.
} 
и бележница, започета 1897, са изводима из неких наших народних бајки. Као и у случају Стевана Сремца, за улазак у књижевну радионицу Милете Јакшића бележнице представљају кључни чинилац. ${ }^{5}$ У њима се налази завидан број фрагмената, предложака и анегдота, народних празноверица - скица које су писцу, касније, послужиле за стварање особеног приповедног света. Богата грађа, сачувана у овим бележницама, потврђује да је знатан број његових приповедака везан за родну Српску Црњу. ${ }^{6}$ Невољно оставши у Црњи као свештеник, Јакшић је заинтересовано бележио празноверице, обичаје и анегдоте, а испод појединих бележака није пропустио да напомене да се ради о истинитом догађају. Своје континуирано интересовање за мистично, фолклорно, зачудно, касније је и литерарно уобличио. Попут бележница, и невелик број сачуваних књига из личне библиотеке Милете Јакшића, такође, потврђује његово интересовање за народне обичаје и народну књижевност. ${ }^{7}$

У досадашњим проучавањима Јакшићевог приповедачког опуса већ је било указивано на присуство фолклорних елемената, које проучаваоци дефинишу углавном као приказ народних обичаја и веровања, односно сујеверја. ${ }^{8}$ Већина приповедака те врсте објављена је у збирци „Мирна времена”. На чињеницу да је етнографске податке „марљиво скупљао, бележио, а поједине записе [...] искористио у прози коју је у послератном периоду објављивао" указује се и у савременим изучавањима Јакшићевог приповедачког опуса (в. Хаџић 2012: 240-241).

Подстицај за Јакшићева интересовања ове врсте проучаваоци његовог дела најчешће проналазе у Гогољевим приповеткама, нарочито у збирци „Вечери на салашу код Дикањке”, и то се нарочито увиђа у поступцима конкретизације тих веровања увођењем наратора који сведоче о личним доживљајима и тако потврђују истинитост мистичних збивања (в. Jovanović 1959: 326-327).

Милета Јакшић се у неколико приповедака бави тематиком смрти и погребних обреда, о којима је писао и у једној од својих бележница, дајући тим својим запажањима наслов Празноверице код сахрањивањ а мртвих (Јакшић 2010: 177180). Поређењем појединих етнографских записа из његових бележница и приповедака јасно се издваја низ подударности не само на нивоу појединих детаља него и читаве фабуле. Тако је идеју за заплет приповетке „Стадо” (Јакшић 1985: 129-136) записао још у Великој бележници коју је започео у Темишвару 1902.

\footnotetext{
${ }^{5}$ Бележнице и дневници Милете Јакшића објављени су у књизи Из моје бележнице.

${ }^{6}$ У једном писму, из 1922. године, он каже: „Од мојих прича ниједна није из ђачког живота - све су из Црње. Обрађујем лагано материјал из своје бележнице” (Јакшић 2005: 110). Касније је Јакшић написао и неколко прича из ђачког живота.

${ }^{7}$ Легат Милете Јакшића налази се на Филозофском факултету у Новом Саду. Један део књига сачувала је породица.

${ }^{8}$ Тако све његове приповетке Иванка Јовановић дели у две доминантне групе: „Pripovetke su po sadržini ili slike piščevog života, njegovog shvatanja, reagovanja na različite sredine u kojima je živeo ili slike pojedinih narodnih običaja i verovanja - sujeverja" (Jovanović 1959: 324).
} 
године (Јакшић 2010: 97). ${ }^{9}$ Читав заплет заснива се на веровању у магијску снагу новчића који се баца за покојником у раку, којим тобоже треба да плати превоз у други свет. ${ }^{10}$ Јакшић поводом овога наглашава да се све чини по древном обичају и накнадно објашњава народна веровања о његовој магијској моћи да преварене мужеве учини слепим, глувим и немим „као што мртвац ћути, ништа не види и ништа не чује...” (Јакшић 1985: 132). ${ }^{11}$ Ове новчиће стари гробар продаје кришом неверним женама, због чега ће на крају испаштати због почињеног греха умирући ,дуго и тешко због гриже савести, од страха да му душа неће бити примљена у вечни покој, већ да ће као проклета лутати по овом свету не налазећи нигде мира" (Јакшић 1985: 135). У опису гробареве смрти такође је присутно старо народно веровање да грешан човек веома тешко умире (Зечевић 2008: 379). У овој приповеци Јакшић је дао и подробан опис ритуала припреме за сахрану: купање, опремање и чување покојника, који се готово у потпуности поклапа са описима из етнографских извора и етнолошке литературе.

Традиционални погребни обичаји у основи су и приповетке „Даћа” (Јакшић 1985: 16-27), ${ }^{12}$ али за разлику од претходне, у којој приповеда о припремању сахране угледног члана заједнице, сеоског газде, које по обичају врше старије жене, у другој се поменути ритуални поступци изводе поводом смрти сиромашног мајстора. Он је у село дошао поодавно и однекуд из света, а пошто није имао породицу, умире сам и без смртне свеће, како се неколико пута наглашава, чиме се у ствари скреће пажња на то да је у овом случају дошло до одступања од уобичајене обредне праксе. То се догодило због његовог ниског социјалног статуса, сиромаштва и недовољне повезаности са члановима сеоске заједнице, који га никада нису прихватали као свог него су га до краја живота сматрали туђинцем. ${ }^{13}$

У приповеткама у којима обрађује ову тематику Јакшић показује да је не само добро уочавао и записао, а и потом детаљно и верно описао погребни обред, него је исправно схватио и њихов смисао, порекло и старину, записујући у једној од својих бележница опаску да у свим „празноверицама, обичајима, мистеријама, обредима нарочито у радњама које су у вези с култом мртвих којима

\footnotetext{
${ }^{9}$ Приповетка „Стадо” први пут је објављена у Летопису Матище српске 1929. године. Упоредити са Јакшићевом приповетком „Погребни новчић” штампаном у часопису Мисао 1922 (Хаџић 2012: 267-269).

${ }^{10}$ Обичај да се мртвац не сахрањује док му се не да нешто новца (тако што му се ставља у уста, под језик, у руку, џеп или се баца у гроб након што га спусте врло је стар и раширен у нашем народу и тумачи се слично као што је и Јакшић навео - да му се нађе на оном свету, односно да плати улаз у рај или превоз преко неког моста или да плати земљу у којој ће лежати, в. Ђорђевић 1984/4: $185-187$.

${ }^{11}$ О употреби предмета чија се магијска моћ заснива на томе што су били у додиру с покојником, односно хтонским светом (в. Јовановић 2014: 218-219).

${ }^{12}$ Приповетка „Даћа” први пут је објављена у Колу Данила Живаљевића 1902. године.

13 „Умрети без свеће сматра се за велику несрећу. Ко умре без свеће мисли се да ће се повампирити, или да ће на ономе свету ићи по мраку, па се неће моћи видети са другим мртвима" (Ђорђевић 1984/4: 175). Паљењем свеће покојнику се заправо шаљу светлост и топлота на онај свет, на ком влада вечна хладноћа и мрак (Зечевић 2008: 411).
} 
се давно заборавио смисао и значење [...] има много паганских елемената" (Јакшић 2010: 178).

Осим погреба као најочуванијег и најкоплекснијег обреда животног циклуса појединца, инспирацију за стварање пружили су му и неки други примери обредно-обичајне праксе. Ту се пре свега истиче приповетка „Литија” (Јакшић 1985: 189-194), у чијем уводном делу подробно описује начин извођења крстоноша, које представљају христијанизовани облик некада много распрострањенијег додолског обреда за призивање кише: ${ }^{14}$

Лагано пољем, креће се поворка. Напред, двоје и двоје, држећи се за руке, иду деца: мушкарци и девојчице у свечаном руху [...] Ти су барјаци, крст и рипиде сасвим напред и предводе овај побожни поход у поља. У средини је велика литија са шест копаља [...] ${ }^{15}$ Затим, под небом свештеник у белој одежди, па онда појци и људи, средовечни и стари људи голих белих глава, у које немилице удара пламено духовско сунце (Јакшић 1985: 189).

Опис литијског опхода поља и навођење црквеног празника Духови као времена извођења овог обреда у потпуности се подудара са етнолошким истраживањима вршеним у Банату која потврђују да се у прошлости литија обавезно носила баш на тај датум. Притом су девојке правиле венце од житног класја и њиме китиле црквене заставе - барјаке и велику литију (БХ: 311-312), што је и Јакшић приказао у следећем одломку:

Литија се враћа натраг, окићена венчићима зеленог жита. Венчићи на крсту, на рипидама, на барјацима, али жалосни мршави венчићи као да су оплетени од зелених конаца.

У селу дочекују литију људи, метанишу пред њом и посипају је житом замахујући рукама као кад се сеје (Јакшић 1985: 190).

Након веома реалистичних описа извођења литијског обреда, његове сврхе и функције у традиционалној сеоској заједници, Јакшић у другом делу приповетке уводи елементе фолклорне фантастике фокусирајући се на лик једног од учесника ове поворке - старог Петра, иначе црквеног појца, који по повратку кући заспи од умора и снива чудесни, пророчански сан. У њему му се суша приказује као ружна, мршава старица, која „нема ниједнога зуба, шиљаста брада додирује јој врх кукастог носа, образи јој упали, оштре вилице као да ће да јој пробију кожу на образима, а на глави коса седа, напрашена" и уместо одеће има дроњке од сиве паучине (Јакшић 1985: 191). Она старом појцу открива да су људски греси главни разлог због ког убија људе и стоку глађу и жеђу, чиме се додатно потврђује да су људи сами криви за сушу која се догодила, што је и на-

\footnotetext{
${ }^{14}$ Крстоноше су учесници опште и заједничке сеоске славе, који обилазе поља и усеве, крећући се ободом сеоског атара и носећи крст, икону и барјак. Литије се сматрају превасходно светковином за род усева и заштиту поља од града и суше (в. Недељковић 1990: 127-130).

${ }^{15}$ Рипиде су махалице (вејало или лепеза) од племенитих метала или од изрезбареног позлаћеног дрвета, у облику округлог диска, на којима су представљени шестокрили серафими, којима се за време богослужења разгоне инсекти са Светих дарова. У духовном смислу представљају небеске бестелесне силе које невидљиво учествују с верницима приликом служења Свете литургије. Барјаци/заставе (хоругве) на којим је изображена света икона су црквени предмети који се носе на литијама и крсним ходовима испред народа, те се стога често називају још и литије (Стошић 2006: 160, 184).
} 
значено у првом делу приповетке: „О, сав народ осећа да због људских безакоња не пушта Бог кишу ево већ седам недеља" (Јакшић 1985: 190), што је такође у складу с увреженим традиционалним представама о узроцима настанка временских неприлика. ${ }^{16}$

У приповеци „Шта је видео Пера Детлић” обрађује народна веровања о ђаволу и комплекс предања о борби добра и зла. ${ }^{17}$ У причу о њему читаоце уводи неименовани наратор констатацијом: „Све доскора се наше село врло бојало ђавола", чиме се одмах ставља до знања да је ово демонско биће заправо главни лик у приповеци. Одмах потом наставља се приповедање о општинском писару, који је по ђавољем наговору написао љубавно писмо удатој жени, након чега се став читаве заједнице мења, те од тада ђавола сматрају „за невино спадало, за амизантну шаљивчину, који нас лепо весели својим забавним хунцутаријама" (Јакшић 1985: 195)..$^{18}$ После тога однос према ђаволу се поново мења након приче коју приповеда главни сеоски шаљивџија, Пера Детлић, друштву које се окупило у дому старог сеоског свештеника на други дан Божића. Његово причање обилује фантастичним детаљима: описом пакла и Сотоне који седи на свом престолу и покушава да издуби корен светског стабла и тако уништи свет, затим претварање ђавола у дивљу гуску у чијем обличју долеће до села, а потом се претвара у снежну пахуљицу и на крају у старог просјака. Као тобожњи просјак завирује у сваку кућу, да би на крају стигао до дома старог ковача који се сажалио и лепо га угостио. Међутим, ђаво се убрзо разоткрива кад покушава да завади ковача са његовим комшијом који долази да му честита Бадње вече, али ће му планове осујетити ковачева жена која га је пребила гвозденим жарачем. ${ }^{19}$ Притом му спада огртач и указује се дугачки ирн реп, након чега коначно сви схватају с ким су заправо имали посла. Тако ђаво завршава своју посету селу „поруган, избијен, не учинивши никаква зла.” Због свега тога покушаће поново да нанесе штету људима тако што ће пресећи вечно стабло, али то не стиже да

${ }^{16}$ Готово истоветно веровање записано је и у једном етнографском извору: „Суша, претерана киша, град, магле које пију усеве, слане које горе растиње, винограде и баште, јесу само казна за неморалан живот људи и за неиспуњавање воље божје” (Ђорђевић 1958: 556).

${ }^{17}$ Видети напомену бр. 3.

${ }^{18}$ Лик ђавола слично је приказан и у Гогољевој приповеци Вече уочи Ивањдана: он се појављује у људском обличју и знају га под именом Басаврјук, али нико није знао откуда је долазио и зашто, изненада би нестајао „као у земљу да пропадне, ни гласа о њему”, да би се потом исто тако изненада „као да је с неба пао” појавио и опет смуцао по селу, мамио људе да му се придруже у његовим разузданим забавама и сл. На крају сељаци схватају да је Басаврјук у ствари Сотона који је узео човечје обличје. Када су га коначно разоткрили, ђаво се претвара у печеног овна, пехар и наћве. У приповеци Бадње вече Гогољ наглашава да је ђаволу преостала само још ова ноћ „кад може да скита и добре људе наводи на грех," а да ће већ следећег јутра, на први дан Божића, чим прво звоно зазвони на јутрење, побећи „главом без обзира подвијена репа у свој брлог” (в. Гогољ 1991: 89-102; 144-183), што се дешава и у Јакшићевој приповеци, будући да се Божић сматра преломним тренутком у годишњем циклусу, тј. временом обнове и почетка. Више о главним карактеристикама ђавола у српском фолклору в. у: Чајкановић 1994/5: 288-297.

${ }^{19}$ У народу се верује да је свако зло дело које човек врши ђавоље дело: Ђаво ни оре ни копа, већ све о злу мисли и ради (Караџић 1965: 100), односно радује се сваком злу и на зло наводи (Ђорђевић 2015: 20-21). 
уради на време јер је већ освануло божићно јутро: „Сотона тресне длето и чекић, паде на земљу и ријући ноктима окорелу материју рикнуо је тако силно да су задрхтали тврди зидови пакла" (Јакшић 1985: 207). Мотив обарања Космичког дрвета или осе света ${ }^{20}$ заступљен је и у нашим усменим предањима, која су забележена у различитим крајевима. У некима се као ослонац на којем стоји читав свет помиње големи стожер од гвожђа, за који је Бог привезао ђавола, а овај покушава да га преглође, у нади да ће се након тога вратити у рај, али га у томе спречавају анђели који запевају: „Христос воскресе!” (Беговић 1986: 225-226), или се тај стуб чудесно обнавља у последњи час: „Таман ђаво ступ да прегризе, а прогризено место се опет залије” (Грбић 1909: 332). У варијанти забележеној у хомољском крају функцију ђавола преузима велики ирн пас, док Земља стоји на гранама једног дебелог глога, који у пресудном моменту Свети Петар прекрсти штапом и тако се обнови (Милосављевић 1914: 391). У свим варијантама оваквим деловањем ђавола или црног пса, као највероватније једног од његових могућих обличја, ${ }^{21}$ тумаче се узроци настанка земљотреса, што је било познато и Милети Јакшићу који је управо о томе записао у својој бележници:

У неким нар. причама потреси земље приписују се Сатани који је у дубинама везан. Ово схватање је у вези са старијим паганским схватањем по ком се везани зли Бог Тифон лежи испод Етне и избацује ватру из свог ждрела (Јакшић 2010: 148-149).

У разматраном комплексу предања о борби добра и зла и сурвавању или потапању земље долази до изражаја мит о Антихристовом уништењу свемира и његовом обнављању од стране културног хероја, или Месије, што потиче из најстаријег митског слоја о посљетку свијета, који пропада, али се и обнавља (в. Милошевић-Ђорђевић 2006: 126), те и Јакшићева опаска о Тифону и његово довођење у везу са ђаволом из наших предања сведоче да је пажљиво и детаљно проучавао митове ове врсте пре него што је покушао да их књижевно уобличи.

Мотив злих сила и ђавола који наводи људе на зло у основи је и приповетке „Нечиста кућа”, у којој се окосница радње гради на сукобу између мајке и ћерке, која се без њене дозволе и благослова удаје за сиромашног надничара. ${ }^{22}$ Овај њен поступак мајка тумачи као „доказ да јој се кћи ухватила у мреже ђавоље, које су јој сплели и вешто подметнули њени непријатељи, да упропасте и осрамоте и њу и њену кћер...” Желећи да се исплете из тих мрежа, мајка се почела обраћати свим познатим врачарама и бајалицама, које су „узимале воду, бацале угљевље, шапутале нешто и зевале тако јако да им сузе пођу” (Јакшић 1985: 230). Последња у низу до које је дошла била је „чувена надалеко,” а многи су

${ }^{20}$ Универзални стуб (Axis mundi), који истовремено подупире и повезује Небо и Земљу и чија се основа налази учвршћена у доњем свету (Пакао) увек се налази у самом центру универзума, јер се целокупни настањени свет налази око њега. Ова космолошка слика неизоставни је део система света традиционалних друштава (Елијаде 2003: 87).

${ }^{21}$ Ђаво се може претворити у све што пожели: у различите животиње, људе, предмете итд. (в. Ђорђевић 2015: 14), што је, судећи по његовим бележницама, било добро познато и Јакшићу (в. Јакшић 2010: 188).

${ }^{22}$ Приповетка „Нечиста кућа” први пут је штампана у Летопису Матице српске 1927. године. 
је виђали како изводи ритуал призивања ђавола на обали реке која је протицала крај њиховог села. Овај опис налази се и у Јакшићевој бележници:

Жене које имају с њим везу иду ноћу на какву воду па забоду преслицу с вретеном крај обале, на преслицу метну сито и окрећу то сито говорећи неке речи, а ђаво дође па се посади на сито и жене се онда разговарају и договарају с њим о рђавим пословима (Јакшић 2010: 188).

Веровања да врачаре раде с нечистим и да свака која врача није баш чиста јер има за побратима и другара онога што има реп, односно да она шаље ђавола да прави зло другима, забележена су и током етнолошких истраживања у Банату у другој половини 20. века (в. БХ: 275), што сведочи о њиховој дубокој укорењености и очуваности на овом подручју.

Традиционалне представе и веровања о демонским бићима описане су и у уводном делу приповетке „Стадо”, у којој стари свештеник приповеда свом младом заменику о остацима паганске религије у коју сељаци и даље кришом верују, иако привидно исповедају хришћанство. Он тврди да ова веровања нарочито оживљавају ноћу: „,У њиховим душама тада не сија сунце разума, него мистични сутон, прамесечина древне паганске ноћи, која их гута и преображава," и тада се крећу по раскршћима и увратинама, „чепркају по гробовима да пронађу вампира,”23 и сви су „под влашћу демона, врачара, чаралица и бајалица, вештаца и вештица, мора, вукодлака, матића, косаца, прикосаца....водаца.” Потом наводи као конкретан пример једну бабу из њиховог села, за коју сви верују да се ноћу претвара у вештицу која се маже посебном машћу и уз помоћ чаробне формуле: „Ни о дрво ни о камен већ онамо под орах!” излеће кроз оџак и састаје се са другим вештицама под неким орахом или дивљом крушком, где једу дечија срца (Јакшић 1985: 130-131). О описаном прављењу чаробне масти, изговарању наведене магијске формуле пре полетања и стаблима ораха и дивље крушке као омиљеним местима састанака вештица сведоче и бројни етнографски извори и грађа (в. Ђорђевић 1953: 28-37).

Митским бићима и бројним веровањима о њима Јакшић је посветио и приповетку „Мистерије,”24 чији је првобитни наслов, судећи по једној напомени у његовој бележници, гласио Три јасена. Поводом ње је још записао: „Ковач приповеда о свом чудотворном исцељењу” (Јакшић 2010: 204), чиме је у најкраћим цртама наговестио тему свог будућег дела, пошто приповетка заиста и почиње приповедањем сеоског ковача о сопственим доживљајима натприродног и сусрету са митским бићима. У уводном делу наглашени су основни елементи простора у којем ће се одигравати мистериозно исцељење, али и време у којем се одвија радња:

${ }^{23}$ Стари свештеник овде указује на уврежена народна веровања да се поједини покојници могу повампирити и долазити ноћу у село како би наудили живима. Једини начин да се одврате од тога било је проналажење гробова у којима су покопани и различите методе уништавања њихових тела (више о томе в. у: Ђорђевић 1953: 198-216).

${ }^{24}$ Објављена први пут у Летопису Матице српске 1925. Преведена је на енглески 1927. 
Далеко, на полукружној црти велике равнице, испод хоризонта, као на рубу огромног зеленог диска, видела се у сутону силуета једнога торња, труп једне ветрењаче са четворо непомичних крила и црн масив велике шуме (...) Предвече се зауставише крај оне шуме једна кола с путником који је још јутрос рано пошао онамо и, стигавши најзад, сишао с кола, скинуо пртљаг, опростио се до сутра с кочијашем, који отиде у село да преноћи, а сам остаде крај велике шуме у којој се, на дану растурене сенке, скупљаху на ноћиште (Јакшић 1985: 218).

Централно место у овом опису заузима велика шума, која је, како сведочи запис у његовој бележници, заиста постојала:

Има крај једне шуме у неком спахилуку (код Турске Кањиже) три грдна јасена са гранама спуштеним до земље. Онамо носе болеснике за које се мисли да су нагазили на вилино коло, да их виле које се тамо скупљају, исцеле (Јакшић 2010: 185).

Јакшићу су несумњиво била позната поменута веровања о чудесним исцељењима на основу прича која је могао чути од мештана, као и традиционалне представе о вилином колу. Управо ови мотиви доминирају и у ковачевом приповедању о мистериозној болести која га је задесила још у детињству:

Још као дечко запатио је некакву бољу у ногама, осећао малаксалост, немоћ. Врачаре и пророчице су говориле да је нагазио на вилино коло. Он се доиста сећа да је једне ноћи као шегрт, пасући мајсторова коња у ливадама, на месечини, набасао на некакав круг као зелен обруч, на чијим је крајевима трава већма израсла, и чим је крочио у тај круг ноге му се подсекле, осетио немоћ сео. После му букну једна нога у листовима (Јакшић 1985: 218).

Цитирани одломак илустративан је пример народних веровања о вилинском колу, односно о његовом изгледу, времену када је опасно нагазити на њега (ноћу, у глуво доба), ${ }^{25}$ као и казни која потом неминовно следи. Опис вилиног кола у потпуности одговара онима који су записани у различитој етнографској грађи, а најрепрезенттивнији међу њима свакако је онај који је објавио Вук Караџић: „Виле никоме неће зла учинити докле их ко не увриједи (нагазивши на њихово коло, или на вечеру, или друкчије како), а кад их ко увриједи, онда га различито наказе: устријеле га у ногу или руку, у обје ноге или у обје руке, или у срце, те одмах умре” (Караџић 1852: 61). ${ }^{26}$ О томе да су Јакшићу такође била добро позната наведена веровања сведочи и одломак о вилама из његове бележнице:

Виле - нису непријатељи људима и хоће да им само онда нахуде, кад их људи увреде, нагазе на њихово коло итд. На лединама се често могу наћи некакви кругови, по чијим је крајевима трава већма нарасла. Те изгледају као широки, повећи обруч. То су, кажу, вилина кола и људи се јако чувају да у те кругове не ступају ногом, јер их може зло да снађе (Јакшић 2010: 184).

${ }^{25}$ Овај термин истиче тишину као једно од кључних својстава ноћи, а традиционална веровања описују га као мртвило свеколике природе. Оно почиње око поноћи, а прекидају га гласови првих (поноћних) петлова (Bratić 2013: 29-30).

${ }^{26} \mathrm{O}$ игрању кола као омиљене вилинске забаве и о забрани гажења места (вилино/виље/самовилско коло) на којем су играле в. Ђорђевић 1953: 64-65, 112-114, уп. Беговић 1986: 237; Милићевић 1894: 56; Вукановић 1937: 198-199; Петровић 1948: 341. 
Након уводних мотива о вилином колу и болести као казни, следи тражење лека, односно низ безуспешних покушаја исцељења. Након што су му сеоске врачаре и пророчище протумачиле прави узрок мистериозне болести, ковач спас тражи најпре у конвенционалним облицима лечења, а потом и у различитим облицима традиционалне медицине: „Тражио је лека по докторима, црквама и манастирима. Био је и на једном извору у некаквој планини, где се испод земље чује како се служба служи и ђаци поју, али му све то ништа није помогло” (Јакшић 1985: 218-219).

Одлазак у цркве и манастире, али и на исцелитељске изворе такође су познати облици лечења у оквиру традиционалне медицине, о чему постоје бројна сведочења. ${ }^{27}$ Као последњи покушај исцељења описује се спавање под дрветом у шуми коју посећују виле, што је такође илустрација веровања да оне једине и могу да излече болест, будући да су је и проузроковале. Овакав облик магијског исцељивања познат је као инкубација. У нашој етнолошкој литератури најчешће је описиван поступак инкубације под биљком која је у народу позната као јасенак (Dictamnus albus L.), због тога што има лист сличан јасену, а цвета од Ђурђевдана до Спасовдана (СМР: 225). У одредници О Спасову дне Вук бележи о јасенку следеће податке:

У Сријему се приповиједа да уочи Спасова дне ноћу виле откину врх јасенку, зато алосану чељад носе те оставе ону ноћ под јасенком, метнувши код болесника колач хљеба и једну чашу воде а другу вина (као вечеру вили), па сјутрадан ујутру копају под јасенком, и шта нађу (нпр. црва или бубицу каку) оно даду болеснику те изије или у води попије - као лијек који му је вила оставила (Караџић 1867: 177). ${ }^{28}$

Ковач у Јакшићевој причи такође наводи исти датум, односно да је дошао у шуму једне недеље, пред Духове, кад никог није било и на потпуно идентичан начин, као што је већ описано у претходним етнографским изворима, поставља ритуалну трпезу за виле, што се додатно наглашава и пишчевом констатацијом: „Све је он то чинио лагано, пажљиво, као да врши какав обред” (Јакшић 1985: 219). Након тога пада у сан и буди се тек око три ујутро, када је већ увелико свануло, препознаје трагове доласка виле по томе што је „од ракије и воде малко отпијено” и осећа прве знаке исцељења: „Он с радошћу осети да му је лакше, па весело, бодро устаде на ноге, и покупи лишће које беше опало. То ће лишће после метати у воду у којој треба да пере ноге, па ће га болест сасвим проћи” (Јакшић 1985: 221).

${ }^{27}$ „Некад болесника натоваре на кола и возе га којој цркви, манастиру, или какој светиғи (старој црквини или водици, где се држи да има каква светиња). Тамо сместе болесника те полежи на светитељевој раци, читају му молитве, или га купају и запајају оном лековитом водицом" (Милићевић 1894: 55).

${ }^{28}$ Много опширнији опис инкубације под јасенком објављен је у часопису Караиић 1901. године и судећи по детаљима које етнограф М. Бобић бележи, у основи се подудара са Вуковим описом. Оно што је ново у овом опису је мотив сна: болесник не може за дуго да заспи, а кад заспи обично снива о својој болести, како виле долазе и лече га, па му чак одређује и дан кад ће оздравити (Бобић 1901: 41-42). О ритуалу инкубације под јасенком в. још и радове: Чајкановић 1994/2: 408-415, Зечевић 2008: 666-672. 
Ову причу о чудесном исцељењу или чудну историју, како је писац назива, приповеда сам ковач, увече на Беле покладе, ${ }^{29}$ својим комшијама који су се окупили код њега на поседак (Јакшић 1985: 221). Дакле, и време кад се људи окупљају код њега посебно је маркирано у традиционалној заједници, пошто су Беле покладе биле познате као период када се приређују заједнички сеоски скупови (посела/сијела или прела) попут овог који је Јакшић описао: ${ }^{30}$

Међутим, ковач није једини приповедач, будући да ова Јакшићева фантастична прича „садржи збивање у збивању, односно облик у облику” и два приповедача који „остају не само раздвојени него и на одстојању” (Велмар-Јанковић 1985: 287). Други наративни ток развија се при крају приповетке, када на сцену ступа лик општинског писара који изражава сумњу и покушава да оповргне истинитост испричаног, будући да је био „школован, напредан, атеиста помало” те је сматрао својом дужношћу да се у сваком тренутку бори против „заблуда и празноверица у народу" (Јакшић 1985: 221).

Након тога у разговор се укључују и остали присутни, настаје препирка и они који су веровали у ковачеву причу почињу да приповедају о својим доживљајима те врсте: један од сељака тврди да се током зимске ноћи срео на путу са ђаволом, који га је „смотао под неку ћуприју,” други казивач пак тврди да се у његовом дому једне ноћи Нечастиви приказао у облику голуба, након чега му се жена разболела, а он је успео да избегне исту судбину тако што је на време „скинуо чакшире и навукао их наопачке”. Након прича о сусретима с ђаволом, започињу казивања о вештицама, будући да их је у селу наводно било много, а притом поједине директно именују и износе веровања о томе како се оне могу препознати помоћу белог лука, пошто не подносе његов мирис (Јакшић 1985: 222-223), о чему је Јакшић такође писао у својим бележницама (в. Јакшић 2010: 184). На крају прелазе на веровања о тодорским коњима, који баш у то време - увече на Беле покладе почињу да иду по селу и газе људе на које наиђу, а своје тврдње поткрепљују конкретним примерима: „Зна се за неке људе и жене које су газили тодорски коњи. Они и сад могу да покажу печате од њихових копита на својим леђима” (Јакшић 1985: 223). ${ }^{31}$ Чак ни ово последње није било довољно

${ }^{29}$ Беле покладе су последњи дан тзв. Беле (сирне или сиропусне) недеље, седмице пред велики или ускршњи пост, односно недеља уочи чистог понедељка. Ускршњи пост увек започиње на Чисти понедељак, то јест сутрадан након Белих поклада и траје све до Ускрса (Босић 1996: 209). Покладни дан је највеселији дан у току ове седмице, када се спрема храна у изобиљу, а сам тај дан испуњен је разним играма и шалама (Недељковић 1990: 23).

${ }^{30}$ У току Беле (Сирне) седмице време се весело проводи на великим заједничким скуповима $($ сијела), на којима млади певају, играју коло или изводе забавне игре, загонеће се и изговарају се шаљиве брзалице, причају „смијешне приповедке,” да би се обично све завршавало приповедањем „о страшилима, вештицама, морама, мађионицама, вукодлацима и вилама.” Приликом причања о нечастивим силама, приповедач се на крају обраћа следећем: „Ако је лаж, предавам ти лаж на част, па причај и ти штогоћ, да не останеш јалов” (в. Памучина 1867: 46, 61).

${ }^{31}$ Свети Тодор или Теодор Тирон у православној цркви празнује се 17. фебруара/ 2. марта и прве суботе у ускршњем посту, а у народу му је посвећена читава Тодорова недеља, односно прва недеља ускршњег поста. Од свих дана у Тодоровој недељи нарочито се празнује Тодорова субота (Недељковић 1990: 209, 237-239). За Тодорову суботу везана су разноврсна веровања и обичаји 
убедљиво за општинског писара, који и даље тврди да су то све „празноверице и бапске приче" и усред свог надахнутог говора изненада примећује да су сви остали неопажено напустили скуп, а да је он остао сам са ковачем. Након тога приморан је да се сам враћа кући у глуво доба, што јасно сугерише и следећи опис: „Нигде светлости на прозорима, ни псећег лавежа, ни петлова кукурика. Као да је све изумрло" (Јакшић 1985: 223). ${ }^{32}$ До наглог преокрета долази кад се и сам суочи са тодорским коњима за које је до малопре тврдио да су глупост и наивна детињарија:

Уједанпут - он ни данас не зна откуд ни како - крај њега, преко њега, не сећа се тачно, пролети, прелети коњ, сенка, фантом од коња, притиште га као ваздух, као лак замах ветра, и он се занесе у страну и чучну да не би пао (Јакшић 1985: 224).

После првог сусрета са тодорцима на улици и паничног бега у кућу, у којој је пронашао уточиште од нечистих сила, дешава се још једна необична епизода:

Размишљање му прекиде некакав шум, топот. Срце му опет залупа. Он ослушну не дишући. Тишина. Месечина улажаше кроз прозоре у његову собу и обасјаваше је тако да се предмети у њој могли распознавати. Опет шум, топот, сада много јаснији, ближи, код прозора. И он лепо чу коњски бахат, а мало затим крај прозора прође коњ, застаде, погледа на прозор, и оде даље чешући се о зид. Филозоф нагло одскочи од кревета, дрхћућим рукама извуче из фиоке од стола нож и виљушку, па их забоде у сто унакрст. То је био начин да се напаст одагна (Јакшић 1985: 225).

У белешци о тодорским коњима Јакшић их још назива Тодорчићи и хроми коњи, а износи још и низ традиционалних веровања о времену њихове активности, као и о поступцима за заштиту од њих и казнама које стижу људе који се не придржавају свих забрана у току Тодорске недеље (в. Јакшић 2010: 183-184), ${ }^{33}$ што је све употребио приликом писања ове приповетке, и могло би се чак рећи

\footnotetext{
- кување пшенице (кољива), освећивање и дељење за душу покојника, прављење обредних пецива (посне погаче) или у облику потковице, копита или коња (тодорчиће) као дар којим ће умилостивити Тодорове коње (Босић 1996: 218-220). Сељаци према томе какво је време тог дана, погађају каква ће бити цела година: Каква је Тодорица, таква је годиница (Филиповић 1986: 42). Поред црквеног постоји и народни култ Св. Теодора, који нема никакве везе са хришћанством. Наиме, за овај период везано је веровање у демонска бића - тзв. тодорие/ тодорчиће или Тодорове коње, које замишљају на разне начине: као црне и са јахачима, или беле без јахача и из ноздрва им избија пламен, а веома је распрострањено и веровање да Тиодор јаши на белом коњу, огрнут белим чаршавом и носи ораћи ланац којим звечи (в. Филиповић 1986: 31, 45, 48).

32 У овом опису доминира, поред тишине, и одсуство светлости, што је потпуно у складу са народним веровањима да је тодоричи не подносе, а та њихова повезаност са мраком сведочи о вези са нечистим покојницима, односно да ова демонска бића заправо представљају утеловљење њихових душа (Агапкина 1999: 147).

${ }^{33}$ Све наведене ритуалне радње и забране указују на то да се током Тодорове недеље одавала почаст покојницима и да су они испраћани у други простор, а у исто време, предузимају се и мере заштите од нечистих покојника, који нису одживели свој век на земљи и непријатељски су расположени према људима. Сам свети Тодор може се схватити као митолошки пастир душа, који је у стању и да сурово кажњава људе ако су обављањем одређених послова повредили његово невидљиво стадо. Све се дешава баш у овом периоду који је схватан као гранично време које се, на астрономском плану, исказивало као прелаз из зимског у пролећно-летњи период, а на социјалном као раздвајање људског од нељудског, односно испраћање душа покојника из људског простора (CM: 533).
} 
да је у „Мистеријама” у највећој мери и на најкреативнији начин успео да својим запажањима из бележница да финални уметнички облик.

Дакле, Јакшићеве белешке о народним обичајима и веровањима сведочи о томе да је помно слушао и записивао све што је током свог борављења у сеоској средини, у најнепосреднијем контакту са људима који су још увек живели у складу са традиционалним поимањем света, могао чути и видети. Притом, прикупљање такве грађе за њега је имало и посебну сврху, будући да је већину етнографског материјала веома креативно употребио приликом писања приповедака с тематиком из сеоског живота. Пажљивија анализа његовог целокупног приповедачког опуса показује да је интересовање за ове области народног живота у његовом случају било континуирано, јер је уочљиво већ у раној фази стваралаштва (нпр. приповетка „Шта је видео Пера Детлић”), да би се продужило и у наредној збирци („Литија”, „Даћа”), па све до последње, у којој су објављене и две уметнички најуспелије, али и по заступљености фолклорних мотива и елемената фолклорне фантастике најупечатљивије приповетке („Мистерије”, „Нечиста кућа"). Међутим, чак ни након детаљног упоредног ишчитавања његових бележница и приповедака није могуће поставити јасну границу између онога што је знао о нашој традиционалној култури на основу непосредног, личног искуства и накнадних сазнања на основу литературе коју је читао о тим темама (дела Вука Караџића, етнографски зборници и часописи у којима су објављивани прилози из народног живота и сл.), о чему такође сведоче поједини цитати у његовим бележницама, као и увид у његову приватну библиотеку. Без обзира на то који су извори заиста били примарни, неоспорно је да је Милета Јакшић био врстан познавалац наше традиционалне културе и усмене књижевности, те је захваљујући вештини транспоновања разнородних фолклорних мотива у знатној мери обогатио свој приповедачки опус, који је управо због значајног удела фолклорне фантастике и данас занимљив и подстицајан за проучавање.

\section{ЛИТЕРАТУРА}

Агапкина 1999: Татьяна А. Агапкина, О тодорцах, русалках и прочих навях, Studia mythologica Slavica, 2, 145-160.

Аноним [Ј. Скерлић?] 1901: Милета Јакшић. Приче. Звезда, II, 4, 490.

Беговић 1986: Никола Беговић, Живот Срба граничара, Београд: Просвета.

Bratić 1993: Dobrila Bratić, Gluvo doba: predstave o noći u narodnoj religiji Srba, Beograd: Plato.

БX: Банатске Хере, ур. Мил. С. Филиповић, Нови Сад: Војвођански музеј, 1958.

Бобић 1901: Михаило Бобић, Јасенак, Каращић, III/2, 41-43. 
Босић 1996: Мила Босић, Годишњи обччаји Срба у Војводини, Нови Сад: Музеј Војводине.

Велмар-Јанковић 1985: Светлана Велмар-Јанковић, Милета Јакшић, приповедач, у: Милета Јакшић, Нечиста кућа, Београд: Просвета (Библиотека Баштина), 243-292.

Вукановић 1937: Татомир Вукановић, Лена самовила са Косова, Јужни преглед, год. 11, бр. 4-5, 198-202 .

Vučković 1990: Radomir Vučković, Moderna srpska proza, Beograd: Prosveta.

Грбић 1909: Саватије М. Грбић, Српски народни обичаји у срезу бољевачком, Српски етнографски зборник, XIV, Београд: CКА.

Гогољ 1991: Н. В. Гогољ, Вечери у сеоцету крај Дикањке, Сабрана дела, Књ. I, Београд: Југославија публик.

Ђорђевић 1958: Драгутин М. Ђорђевић, Живот и обичаји у Лесковачкој Морави, Српски етнографски зборник, LXX, Београд: САНУ.

Ђорђевић 1953: Тихомир Р. Ђорђевић, Вештица и вила у нашем народном веровању и предању; Вампир и друга бића у нашем народном веровању и предањy, Београд: Српска академија наука/ Научна књига.

Ђорђевић 1984/4: Тихомир Р. Ђорђевић, Неколики самртни обичаји у Јужних Словена, Наш народни живот, Књ. 4, Београд: Просвета, 124-246.

Ђорђевић 2015: Тихомир Р. Ђорђевић, Ђаво у нашем народном веровању, прир. Н. Јовановић, Книжевна историја, 157, 9-44.

Елијаде 2003: Мирча Елијаде, Свето и профано, прев. 3. Стојановић, Ср. Карловци - Нови Сад: Издавачка књижарница Зорана Стојановића.

Зечевић 2008: Слободан Зечевић, Српска етномитологија, прир. Б. Јовановић, Б. Зечевић, Београд: Службени гласник.

Јакшић 1935: Милета Јакшић, Мирна времена (Приповетке), Београд: СКЗ.

Јакшић 1985: Милета Јакшић, Нечиста кућа, приредила Светлана ВелмарЈанковић, Београд: Просвета (Библиотека Баштина).

Јакшић 2005: Судари Милете Јакшића, преписка, приредили Миливој Ненин и Зорица Хаџић, Нови Сад: Матица српска.

Јакшић 2010: Милета Јакшић, Из моје бележнице, приредила Зорица Хаџић, Нови Сад: Академска књига.

Јовановић 2014: Бојан Јовановић, Магија српских обреда, Београд: Службени гласник.

Jovanović 1959: Ivanka Jovanović, Nekoliko karakterističnih crta pripovedačke proze Milete Jakšića, Godišnjak Filozofskog fakulteta u Novom Sadu, IV, 323-330.

Караџић 1852: В. Стеф. Караџић, Српски ријечник истумачен њемачким и латинскијем ријечима (1852): Сабрана дела Вука Караџића, Књ. 11, приредио Ј. Кашић, Београд: Просвета, 1986.

Караџић 1867: Вук Стеф. Караџић, Живот и обичаји народа српског, у: Етнографски списи, прир. Мил. С. Филиповић, Београд: Просвета, 1972. 
Караџић 1965: Вук Стеф. Караџић, Српске народне пословище, прир. М. Пантић, Сабрана дела Вука Караџића, Књ. 9, Београд: Просвета.

Милићевић 1894: Милан Ђ. Милићевић, Живот Срба сељака, Српски етнографски зборник I, Београд: СКА.

Милосављевић 1914: Сава М. Милосављевић, Српски народни обичаји из среза хомољског. Српски етнографски зборник, XIX, Београд: СКА.

Милошевић-Ђорђевић 2006: Нада Милошевић-Ђорђевић, Од бајке до изреке: обликовање и облиии српске усмене прозе, Београд: Друштво за српски језик и књижевност Србије.

Недељковић 1990: Миле Недељковић, Годишњи обичаји у Срба, Београд: „Вук Караџић”.

Памучина 1867: Јоаникије Памучина, Покладање месни и бијели поклада у Хериеговини, Србско-далматински магазин, XXVI: 44-64.

Петровић 1948: Петар Ж. Петровић, Живот и обичаји народни у Гружи, Српски етнографски зборник, LVIII, Београд: САНУ.

Протић 1901: Јован Протић, Српска белетристика у год. 1900, Нада, VII, 2,314 .

СМ: Словенска митологија, енщиклопедијски речник, ур. Љубинко Раденковић и Светлана М. Толстој, Београд: Zepter book world, 2001.

СМР: Српски митолошки речник, прир. Шпиро Кулишић, Петар Ж. Петровић, Никола Пантелић, 2. допуњено изд., Београд: Етнографски институт САНУ/ Интерпринт, 1998.

Стошић 2006: Љиљана Стошић, Речник ирквених појмова, Београд: Завод за уџбенике и наставна средства.

Филиповић 1986: Миленко С. Филиповић, Трачки коњаник: студије из духовне културе, Београд: Просвета.

Хаџић 2012: Зорица Хаџић, Тиха пристаништа Милете Јакиића, Београд: Службени гласник.

Чајкановић 1994/2: Веселин Чајкановић, Студије из српске религије и фолклора: 1925-1942, Сабрана дела из српске религије и митологије, Књ. 2, Београд: Српска књижевна задруга/ БИГЗ/Просвета/ Партенон М.А.М.

Чајкановић 1994/5: Веселин Чајкановић, Стара српска религија и митологија, Сабрана дела из српске религије и митологије, Књ. 5, Београд: Српска књижевна задруга/ БИГЗ/Просвета/ Партенон М.А.М. 
Jasmina S. Jokić

Zorica P. Hadžić

\title{
FOLKLORIC ELEMENTS IN NARRATIVE CREATIONS OF MILETA JAKŠIĆ
}

\author{
Summary
}

The paper explores the folkloric elements in novels of Mileta Jakšić. Writer's interest for folkloric motives and folkloric fiction was continual and dated from the very beginning of his literary work. Encouragement for representation of folkloric elements could be find in Russian literature influence (N. V. Gogol), and even more in Jakšić personal inclination to collect and record ethnographic data. In the core of our investigation were novels: "Herd" (,Stado”), „Daća” ("Funeral meal”), "Procession” ("Litija”), "Haunted house” („Nečista kuća”) and "Mysteries" („Misterije”), where we recognized the examples of customized ceremonial practice and national religious beliefs and tradition (funeral ceremonies, credence in demons, demonic beings, evil abilities, fairies, witches, Sent Theodor horses, miraculous healings...). It was noted that Mileta Jakšić proficiently incorporated folkloric elements in his prose and efficiently treated them literary.

Key words: Mileta Jakšić, novels, folkloric motives, folkloric fantastics, mythical/ demonic beings, beliefs, demonological legends. 